\title{
STRATEGIC AGILITY ORIENTATION? THE IMPACT OF CEO \\ DUALITY ON CORPORATE ENTREPRENEURSHIP IN PRIVATIZED \\ VIETNAMESE FIRMS
}

\section{Authors:}

\section{Hong T.M. Bui, Huong, T. Nguyen \& Vinh Sum $\underline{\text { Chau }}$}

\begin{abstract}
This study examines the impact of CEO duality (a chief executive operating chair of board and leader of a firm) of newly privatized Vietnamese firms on the level of corporate entrepreneurship; this understanding is used to throw light on the extent to which a position of strategic agility is achieved. Specifically, does CEO duality enable firms to keep consistent with their vision, while remaining flexible in their business model? Data from a survey of 114 CEOs of board and top management team members in privatized firms in Vietnam were collected and examined through a combination of agency theory and stewardship theory. The research finds that CEO duality does not necessarily lead to a higher degree of entrepreneurial activity in privatized Vietnamese firms. The results have policy implications for shaping corporate governance, and management implications for firms striving to be competitive, in ways that advance corporate entrepreneurship in economies such as Vietnam that are both emerging and pursuing privatization.
\end{abstract}

Keywords: CEO duality, corporate entrepreneurship, strategic agility, privatization. 


\section{Introduction}

The relatively nascent and emerging literature on strategic agility deals with individual firms' ability to concentrate on achieving their strategic vision, while remaining agile in their approach (Lewis et al., 2014). This imperative is driven by increasingly competitive environments, in which a leader's ability to make decisions quickly is important, but which often requires trade-offs with respect of the position held. This has meant a firm must have the ability to sense external ecosystems and internal activity while making the appropriate amendments to, or switching between, business models (Doz and Kosonen, 2010). Despite the recent attention to this emerging phenomenon (see for example, Weber and Tarba, 2014), research has focused on it at a micro-firm level to understand its antecedents and influences (Arbussa et al., 2017; Doz and Kosonen, 2010). However, the desired state relating to strategic agility is one attributable to an orientation of groups of firms that are striving to achieve. Hence, this article examines if firms can achieve a strategically agile orientation, by which leaders had duality in the position they hold within the governing board, while enabling the firm to achieve outcomes that encompass competitive advantage and strategic renewal. Thus, this article examines the impact of chief executives holding combined positions in a board on their corporate enterprise performance, and draws insights for understanding strategic agility at the macro-economic level (referred loosely herein as strategic agility orientation). This is examined by treating components deemed key to strategic agility, such as processes and actions, etc, that enable flexibility in a firm's business model, that are also important in corporate entrepreneurship. The connection is made that the conditions of strategic agility will be similar to those of corporate entrepreneurship in a transitioning economy as Vietnam, and therefore examining these measures of corporate entrepreneurship will enable understanding whether or not CEOs 
holding a dual board/chair position represents a strategic agility orientation for the Vietnamese firms.

To put into technical terms, when chief executive officers (CEOs) go beyond a monolithic orientation of board conduct, this is CEO duality, such that a firm allows the CEO and board chair positions to be combined (Gove et al., 2017) which enables potential swiftness in making decisions. The benefits and purpose of strategic agility are similar to an established concept of corporate entrepreneurship, defined formally as "a process of organizational renewal that has three distinct but related dimensions: innovation, venturing, and strategic renewal" (Zahra, 1993, p. 321). Corporate entrepreneurship has been argued as an important tool for achieving competitive advantage (Covin and Miles, 1999), enhancing international performance (Brouthers, Nakos and Dimitratos, 2015), and improving the dynamic competencies that underlie firm performance (Wiklund, 1999). Corporate entrepreneurship intrinsically involves ideas and initiatives that are new and unproven (Brouthers et al., 2015) and thus entails a high degree of risk and uncertainty (Garrett and Holland, 2015). This is similar to strategic agility in the way firms strive to respond quickly, seize opportunities and change direction. We argue for the context of Vietnamese firms, this is a representative position as their survival conditions warrant the agility.

These attributes of agility and intended gains raise questions regarding which business governance and board-related mechanisms are most appropriate for managing and driving corporate entrepreneurship. In particular, there is some debate concerning the extent to which corporate entrepreneurship might be affected by the extent of separation from, or combination between, the functions of chair and CEO (Connelly, et al, 2010). Yet, there remains uncertainty whether combining the roles of chair and CEO (hence, CEO duality) stimulates or hampers corporate entrepreneurship. This gap in the extant literature is 
particularly problematic for informing economic development in transition economies, for which the need and motivation to foster entrepreneurship (and achieve a strategically agile orientation) are strong.

This study addresses this gap in the context of a communist transitional emerging economy of Vietnam where the dominant nature of business dictates the need to achieve attributes representative of a strategic agility orientation. This context is important for at least three other key reasons. First, unlike the majority of research to date on CEO duality (e.g., Adrian, Wright and Kilgore, 2017; Gove et al., 2017) that has been undertaken in WEIRD (western, educated, industrialized, rich, and democratic) economies (Henrich, Heine and Norenzayan, 2010), the present study collected data from an eastern emerging economy with a young population and fast growth rate of Vietnam. The government has substantially modified the institutional arrangements applicable to business (Santarelli and Tran, 2012) to facilitate competitive entrepreneurship. Second, Vietnam reformed its system of state-owned enterprises (SOEs) by implementing privatization schemes for many but not all industries, creating a wide range of ownership structures, so it might be the case that achieving a strategically agile orientation is possible in some industries exhibiting various characteristics. Given this context, entrepreneurship has been blooming in this emerging economy (Nguyen, Sullivan Mort, and D'Souza, 2015). Third, Vietnamese policy makers continue to devise laws, regulations, policies and programs to encourage innovation and growth (Aubert, 2005). In this way, Vietnam serves as an applicable and timely setting for an empirical investigation of the influence of corporate governance structures on corporate entrepreneurship in a developing economy undergoing transition with firms wanting to achieve high competitiveness, efficiencies (and thus strategic agility). Understanding the 
drivers of corporate entrepreneurship in Vietnam's dynamic economic setting will inform policy makers and interested researchers.

Three main contributions are offered by the study. First, it advances corporate governance research by suggesting that the longstanding and dominating theories, such as agency theory or stewardship theory, are not the only that can help predict and explain corporate governance in transition economies like Vietnam. Instead, the present research argues that the standard agency-theoretical model alone is inadequate and researchers must look to such emerging ideas as strategic agility, and suggests how the impact of CEO duality on corporate entrepreneurship in the specific context of Vietnam is representative of a strategic agility orientation. Second, the study provides management and policy insights for shaping corporate governance in ways that foster corporate entrepreneurship in privatized firms in emerging economies. And last, this study challenges the notion of publication bias namely that journals tend to publish only 'significant' results (Homberg and Bui, 2013) while 'non-significant' results, if studies are well designed, are still valid and add value to the literature.

\section{Theoretical Background}

As Vietnam is a transitioning economy and has undergone significant policy and economic restructuring in the past few decades, the focus of research has recently been on how best to manage effectively and become competitive, particularly for (mainly privatized) firms against their international counterparts. The idea that firms should try to achieve strategic agility has recently emerged to concern the ability of firms to remain on track to achieve their strategic objectives while remaining nimble (Doz and Kosonen, 2008). The more recent definition by Weber and Tarba (2014), "the ability of management to constantly and 
rapidly sense and respond to a changing environment by intentionally making strategic moves and consequently adapting the necessary organizational configuration for successful implementation" (p.7), which includes key components as processes, actions, structures, culture, attributes, skills, and relationships, has close resemblances and gives rise to how it can be measured in the form of corporate entrepreneurship. The similarity is in the items used in components of the latter, such as strategic renewal on questions like 'change of competitive approach', 'initiate new programs to improve productivity', etc. Given the vast majority of Vietnamese firms are privatized and smaller enterprises, by understanding these firms make it an appropriate group of corporations to research the impact on corporate entrepreneurship and how the situation can represent that of strategic agility. This is a stark difference from conventional western research that had preferred single case examples to understand the leadership behaviors that represent strategic agility (eg. Doz and Kosonen, 2008; Arbussa et al., 2017).

In such research, the roots of strategic agility go back to effective and flexible systems, such as those of the Toyota Production System (Adler et al., 1999), and the importance to associate with leadership styles (Lewis et al., 2014). However, what has not been researched is the characteristic of CEO duality as a form of leadership style on the ability to maintain strategic direction and remain flexible in response to external environmental conditions. A traditional approach has been in the form of agency theory, particularly where it is found that remuneration committees of CEOs are more aligned with achieving strategic direction for companies with top management board that are more outsider-dominated (Conyon and Peck, 1998).

Agency theory has been the central literature base in many scholarly debates on the issue of the effectiveness of CEO duality as an internal governance mechanism (see 
Eisenhardt, 1989). Dominating corporate governance research, agency theory assumes managers are self-serving, individualistic and bounded by rationality, and may behave opportunistically at the expense of the interests of shareholders (ibid). Presumably, the goals and risk preferences of shareholders and agent managers are incongruent (Means, 1991), a divergence that generates agency costs (Fama, 1980; Jensen and Meckling, 1976). In this way, a system of CEO duality is unlikely to benefit all stakeholders, and decisions made are perhaps less in touch with the outside interests of the firm. The effectiveness of the use of agency theory in researching CEO duality and orientations of effectiveness have been extensively researched. For example, Finkelstein and D'Aveni (1994) find that CEO duality is most commonplace in situations where leaders do not otherwise have high power, but take a more singular role if the firm's performance is already high.

In a similar vein, stewardship theory posits that individuals are motivated not only by self-interest and economic considerations but also by self-actualization through intrinsic rewards attained through work and the achievement of personal values and goals (Davis, Schoorman and Donaldson, 1997a; Donaldson, 1990). In theory, agents act as an organization's stewards, committed to the attainment of company (and collective) objectives. If the interests of the stewards are not aligned with those of the owners, the former will "place a higher value on cooperation than defection" (Davis et al., 1997a, p. 24); they will be more inclined to prioritize and pursue their organization's interests (Donaldson and Davis, 1991). In principle, managers/leaders act as good stewards of corporate assets and are loyal to the company. Misangyi and Acharya (2014) find the CEO incentive alignment depends and success of CEO singularity/duality depends on how well it combines with other mechanisms within the governance bundle. Their exploratory qualitative study indicates some governance systems are substitutes and some are complements, but CEO 
incentives are complementary and support a duality role if the overall governance bundle is sound.

In this way, the present study does not re-research sound contributions on either agency or stewardship theories, but borrows their basic premise to guide the core hypothesis for the context of transitional economies as the strategic agility literature is more nascent and has its close resemblances in this context. The benefits are because, first, agency theory and stewardship theory offer slightly different perspectives on human behavior (Davis et al., 1997a) which make them complementary rather than competing ideas, as each is more applicable to certain executives and situations (Wasserman, 2006); and second, existing research on CEO duality is indifferent in the support of either agency theory or stewardship theory (Jackling and Johl, 2009), making them neutral in throwing light on understanding the impact on corporate entrepreneurship (and strategic agility orientation).

\section{Context}

Vietnam's entrepreneurs have historically operated within a hostile institutional environment, i.e., in the almost complete absence of formal institutions (Nguyen, 2005), making it difficult to be more creative or have the freedom in considering strategically agile orientations of business, such as sensing environments (eg. Doz and Kosonen, 2010), etc. However, the country's environment has gradually become more conducive to entrepreneurship and the need to reflect external competitive environments, allowing the freedom to experiment with business models and leadership orientations that are often seen paradoxical (see Ivory and Brooks, 2018). Vietnam has established herself as a prime example of robust growth (McMillan and Woodruff, 2002). Doi Moi has significantly facilitated the building of market institutions and infrastructure through various laws and regulations and the provision of support for the private sector (Nguyen, 2005). These 
institutional developments have created a favorable environment for entrepreneurship and the number of private enterprises has increased dramatically, from 414 private firms in 1990 to 69,874 in 2012 (General Statistics Office of Vietnam). By the end of the 2000s, market conditions had changed markedly, and access to markets and buyers had become increasingly favorable (Steer and Sen, 2010). Undoubtedly, the private sector has played an important role in Vietnam's economic growth and competition models have become key in ensuring the firms' survival.

Corporate governance in Vietnam is significantly affected by institutional arrangements rooted uniquely in the country's political system and ideology. The corporate governance system is regulated by Vietnam's 1999 Enterprises Law, 2005 Enterprises Law and 2005 Securities Law. Vietnamese corporate governance incorporates several different legal systems; although Anglo-American company law principles are now becoming dominant (Gillespie, 2002), a mix of influences continues. While corporate governance standards award the CEOs of privatized firms the power of an agent, this is not the case in reality. Many CEOs of privatized Vietnamese firms held a management position in former state-owned enterprises (Vu, 2005), before privatization (Gainsborough, 2009). Such CEOs may be advantaged in their position in the privatized firm because they understand how the business works and have connections with many of the business' stakeholders.

Given that the government can retain a considerable proportion of its stake in privatized companies, it is appropriate to examine corporate governance in terms of the role of the state vis-à-vis the board. Privatized firms can be categorized into three types according to the degree of state control: majority share, minority share and no control. Where the state owns more than 51 per cent of the capital share, firms are referred to as majority shareholding firms; those with less than 51 per cent retained by the state are 
minority shareholding firms. In majority shareholdings, the controlling agencies appoint the directors and have veto power over their appointment. Notably, the Chief Party Secretaries (the Communist Party's ideological leads in those companies) of these agencies also have the responsibility for approval of those appointments. Consequently, except for the firms for which the state has minority or no share, boards of directors of privatized firms tend to be dominated by representatives of the controlling agencies, which include the ministries and state capital management agencies or local government.

Social culture is another important factor. In Vietnam's firmly embedded East Asian culture, social collectivism is prevalent (Bui and Baruch, 2012). Therefore, the success of one's organization may be considered more important than individual achievements. Executives in this context typically have a long tenure, with a commensurately strong commitment and sense of duty to the company as a collective organization. Such executives may, therefore, feel bound to their company's performance and take the credit for its organizational success. Such success is beneficial to the executives' careers, making them less likely to forego longer-term opportunities for the company for the sake of short-term investment returns.

In addition, corporate entrepreneurship seems to be fairly new to Vietnamese firms due to the history of a close and planning economy. Firms tend to prefer short-term approaches based on net profit rather than business growth (Swierczek and Thai, 2003). In addition, culturally due to the agriculture of small rice paddles in the North, Vietnamese people lack vision for long term development (Tran, 1999). This questions the extent to which a strategically agile orientation can be truly achieved, where the idea is to remain forward looking in the form of strategic direction but maintain a flexible business model (Arbussa et al., 2017). In other words, businesses do not tend to invest in long term 
investment, such as research and development, innovation, or venturing. This can reflect onto business where firms lack commitment to corporate entrepreneurship.

\section{Hypothesis Development}

On the one hand, a suggestion supported by agency theory is that the separation of power between CEO and chair is positively related to long-term decision-making, and therefore improves firm performance (Barnhart, Marr, and Rosenstein, 1994; Daily and Dalton, 1994). However, empirical studies provide evidence of a negative effect of CEO duality on risk-taking and firm performance. Taking the latter as a dependent variable, this negative effect is evident both in developed economies (Ellstrand, Tihanyi, and Johnson, 2002; Kiel and Nicholson, 2003; Rechner and Dalton, 1991) and in developing economies such as China (Liu, Miletkov, Wei and Yang, 2015). With regard to long-term investment decisions, Zahra, Neubaum and Huse (2000) found a negative effect of CEO duality on corporate entrepreneurship, suggesting the CEO may behave opportunistically and influence the firm to reject investment in corporate entrepreneurship.

Privatized firms in Vietnam, emerging as they have from state-owned enterprises and moving to an entirely new competitive environment, may be subject to less managerial supervision (Bolton, 1995). Fama and Jensen (1983) state that ownership and control are more a case of union than separation in young entrepreneurial firms may be more applicable to the Vietnamese case; executives of newly privatized firms may see themselves more company owners than agents.

On the other hand, stewardship theory seems more applicable to organizations in which weak control systems dictate trust as the basis of collective and collaborative work (Davis, Schoorman, and Donaldson, 1997b). Given the underdeveloped nature of Vietnam's market institutions, trust is more likely to exert a significant force among actors in a 
business relationship than in an economy where market institutions are better established (Nguyen and Rose, 2009). Trusting climates established in these organizations create opportunities for CEOs to behave as stewards (Eddleston, Chrisman, Steier, and Chua, 2010; Van Slyke, 2007).

Thus, in a developing context, for a person who has combined roles of CEO and board chair, and might act as both 'agent' and 'steward', those roles are likely to conflict with each other, and take most of CEO time and energy to engage effectively in corporate entrepreneurship. The following hypothesis is then proposed:

Hypothesis: In newly privatized firms in Vietnam, CEO duality is negatively associated with corporate entrepreneurship.

Therefore, CEOs who have board chair positions combined are unlikely to represent a 'strategically agile' orientation for Vietnamese firms.

\section{Methodology}

\section{Method and sampling}

The direction and magnitude of relationships between CEO duality and the two dimensions of corporate entrepreneurship (innovation and strategic renewal) were analyzed for a sample of Vietnamese privatized firms at a single point in time. The sample population comprised all types of privatized firms in Vietnam, including those sold to the public through share issues, and firms sold to individuals and organizational investors. The sample was limited to firms that had been privatized for at least three years. Moreover, only firms with CEOs who had worked for the firm for at least a year at the time of the study were included.

To obtain information relating to the variables in the model, a combination of survey methods and secondary sources to avoid common method bias (Podsakoff MacKenzie and 
Podsakoff, 2012) was employed. A structured questionnaire survey, which collected data on the two dimensions of corporate entrepreneurship, was supplemented with archival data on board characteristics and ownership structures. These companies' data were collected separately in order to limit the length of the questionnaire. A firm's proxy statements were used to collect detailed information about CEOs, chairmen, and board composition. For the listed companies, data were obtained through the Internet, while data for non-listed firms were collected directly from those firms. The data covered the three-year period from 2010 to 2012. The total amount of time spent on data collection was a year.

Because of the challenges of surveying top managers (Cycyota and Harrison, 2002) in gathering quantitative data, a convenience sampling method was employed. Since convenience sampling risks selection bias (Van Meter, 1990), all possible steps were taken to ensure the diversity of board composition, ownership structure, location and size. As mail and telephone surveys often have poor response rates, an in-person survey (Patton and Baker, 1987) was conducted. Ultimately, 173 CEOs were contacted; 130 CEOs agreed to participate in the survey interview; and full data sets from 114 firms were collected. Those firms range from small ones (from 15 employees) to large ones (up to 6155 employees) with the average of 520.21. 63.2\% of participated firms were in largest cities (i.e. Hanoi and Ho Chi Minh), and the rest were from smaller cities (i.e. Hai Phong, Can Tho, and Tay Ninh). 93\% participants were male, only $7 \%$ female. More than half of them $(56.1 \%)$ had dual roles of CEO and chairman. Their age ranges from 35 to 65 with the average of 51.70 years old. 93.9\% of the participants had undergraduate degrees and above. Their board size ranges from 3 to 11 members, with the average of 4.95 . 


\section{Measures}

Given the debate about the definition and measurement of corporate entrepreneurship, the relevant literature to select appropriate instruments for use in this study was carefully reviewed. The study adapted two measures developed by Zahra (1996), namely innovation and strategic renewal performance (i.e. the two dimensions). The closeness of how the items are close proxies to the defining characteristics of strategic agility by Weber and Tarba (2014) is provided at Appendix 1. CEO duality is a dichotomous variable that takes the value of 1 if the CEO and board chair are separate individuals; the variable takes the value of 0 if the CEO also serves as the company's board chair. Guided by previous studies on corporate governance and corporate entrepreneurship (e.g., Zahra, 1996; Zahra et al., 2000), the following control variables were included: firm location, CEO age, gender, tenue and qualifications, and board size. Data to operationalize the controls were collected from various sources, company websites and company annual reports.

\section{Analytical procedures}

Correlations among all variables are presented in Table 1. The highest correlation values are .52 , at the moderate level. The high VIF indicator is 4.12, much lower than the 'rule of thumb' of 10. Therefore, multi-collinearity is not a concern in this study. The data set was also screened to ensure that assumptions of normality were not violated.

Insert Table 1 here

Multiple regression using STATA software to estimate the models was employed. First, this utilized ordinary least squares (OLS) regression for the continuous dependent variables (i.e., innovation, strategic renewal performance), computing standard errors that are robust 
to departures from homoscedasticity. To reduce potential multi-collinearity and enhance the interpretability of coefficients, the variables used in the interactions prior to creating the product terms (Cohen, Cohen, and Stephen, 2003) were standardized. To address the problem of outliers, the results from the robust regression analyses were reported, which generates OLS estimates that are robust to the presence of outliers. To protect against multicollinearity, the procedures outlined by Neter, Wasserman, and Kutner (1989) were followed and variance inflation factors (VIFs) were used to test for collinearity. Checks for violations of the assumptions in the regression analyses yielded no substantial concerns.

To reduce the noise per degree of freedom, control variables and independent variables, respectively, were iteratively tested and parsed. This approach was employed in previous studies which tried to preserve degrees of freedom in models with small numbers of observations (Bergman and Feser, 2001). The parameters are consistent across alternative specifications. In the results, $p$-values were reported in the main analysis, but the traditionally misleading interpretations of 'statistically significant' or 'insignificant' $p$ values were completely removed (Hurlbert, Levine and Utts, 2019).

\section{Results and Discussion}

Separate analyses were conducted for models relating each measure of dependent variable, corporate entrepreneurship, namely innovation and strategic renewal performance. Table 2 shows the regression results. Because of the small sample size $(\mathrm{N}=114)$, the results may suffer limitations in terms of statistical power. Therefore, a post hoc analysis was conducted to calculate the statistical power for the models that we have tested. The results suggest that both models 1 and 2 have observed statistical powers of 1.00, which are above the 
acceptable threshold of .80 (Hair et al., 2010). Thus, the results do not suffer from this limitation.

\section{Insert Table 2 here}

Table 2 shows a number of interesting findings related to CE. First, CEO gender does not seem to have any impact on firm's innovation $(\beta=-.01, p=.90)$, but slightly have impact on firm's strategic renewal performance $(\beta=.15, p=.10)$. It means that female CEOs tend to have better strategic renewal performance than male counterparts. CEO age has positive impact on firm's innovation $(\beta=.24, p=.04)$, but negative on firm's strategic renewal performance $(\beta=-.14, p=.22)$. This means that among the age range of 35 and 65 , the older CEO is, the more innovation the firm shows. CEO education shows to have positive impact on both firms' innovation $(\beta=.29, \mathrm{p}=.00)$, and firm's strategic renewal performance $(\beta=.19, \mathrm{p}=.05)$. These results show that the higher qualifications that CEOs possess, the higher level of corporate entrepreneurship the firms show. Firm's location has negative impact on firms' innovation $(\beta=-.18, \mathrm{p}=.04)$, but almost no on firm's strategic renewal performance $(\beta=.01, \mathrm{p}=.88)$. This means firms that are located in big cities show to be more innovative than those in smaller cities. CEO's tenure in firm has almost no impact on innovation $(\beta=-.05, p=.61)$, but shows a positive trend toward strategic renewal performance $(\beta=.14, p=.19)$. These results mean CEO's experience in his/her firm does not affect the firm's innovation, but the longer they had been in the form, the more likely it has impact on firm's strategic renewal performance. The size of the firm shows a trend of positive impact on innovation $(\beta=.17, \mathrm{p}=.09)$, i.e. the larger firms are, the more innovative they are. This finding contradicts some studies in the literature that the smaller firms are the 
more innovation they are (e.g. Rogers, 2004). In contrast, size of firms shows almost no impact on strategic renewal performance $(\beta=-.00, p=.98)$. Firm assets show to have positive impact on both innovation $(\beta=.16, \mathrm{p}=.21)$, and strategic renewal performance $(\beta$ $=.20, \mathrm{p}=.14)$. Similar results are seen with the firms' trade on stock market $(\beta=.20, \mathrm{p}=$ .07 ; and $\beta=.15, p=.18$ respectively $)$; and are the size of the board $(\beta=.13, p=.21 ;$ and $\beta=$ $.16, \mathrm{p}=.15$ respectively).

Second, as it was hypothesized that in newly privatized firms in Vietnam, CEO duality is negatively associated with corporate entrepreneurship. The results show that CEO duality has negative impact on firm's innovation $(\beta=-.13 ; \mathrm{p}=.19)$, and firm's strategic renewal performance $(\beta=-.12 ; p=.21)$. The results show a trend of negative relationships between CEO duality and two dimensions of corporate entrepreneurship. Our hypothesis is supported, and that CEOs who have board chair position combined are unlikely to represent a 'strategically agile' orientation for firms, particularly in the context of emerging economies like Vietnam.

As CEO duality shows a trend to have negative impact on the two measures of corporate entrepreneurship, this supports the notion that "organizational changes occur as the result of processes that make organizations more similar without necessarily making them more efficient" (DiMaggio and Powell, 1983, p. 147), which challenges existing studies in developed economies (e.g., Zahra et al., 2000). Furthermore, the complementary union of agency and stewardship theories results in no associations between CEO duality and corporate entrepreneurship (cf. Le Breton- Miller and Miller, 2009), possibly because the benefits and disbenefits are traded-off each other. 


\section{Conclusion}

So, what does this mean for understanding strategic agility, and if Vietnamese firms operate such an orientation? As the empirical study finds that CEO duality tends to have negative impact on corporate entrepreneurship, it would suggest that from a macro-economic level, Vietnamese firms would not be operating a strategic agility orientation of keeping strategic direction and averse of competitive environmental conditions. This would also imply, CEOs operating dual roles may not respectively represent the specific acts of achieving strategic direction by leading the firm and reflecting on the external environment as director of its board. Both theoretical and practical implications of this study are discussed below.

\section{Theoretical implications}

This study is consistent with Filatotchev's (2008) idea that there is no universal "best way" to achieve corporate governance effectiveness; each institutional environment is distinctive. Borrowing usefully from stewardship theory and agency theory has helped explain for the context of Vietnam that CEO duality is actually indifferent to corporate entrepreneurship.

This finding is important in terms of theory development for two reasons. First, researchers in governance, corporate entrepreneurship and strategic orientation might need to understand the phenomenon in the context of fast developing economy with a communist political system differently. In other words, CEO duality does not help corporate entrepreneurship in such a context where many top managers have worked for state-owned companies and the power of the state is still large in the economy (Nguyen and van Dijk, 2012). Second, our study seems to show that the contextual factors, such as the economy's 
history and societal culture might possibly lend insightful explanations, which need further studying in the area.

Though not fully, our study also partly reveals some insight into the applicability of stewardship theory, suggesting that it might be more applicable in the early stage, right after the privatization to set the corporate entrepreneurship direction for the firm. This insight is consistent with the argument that young ventures are less control-oriented than more mature ones, so stewardship theory is better applied to new ventures than to mature ones

(Wasserman, 2006). For the context of strategic agility, this suggests that business models should be set up early on before firms become more established making it difficult to adjust after a while in operation.

\section{Practical implications}

One of the practical implications of this study is to increase the awareness of the importance of corporate entrepreneurship among businesses in Vietnam. This helps them plan for strategic development with a focus on innovation and competitive strategic renewal.

In addition, the findings have important implications for Vietnam and its efforts to employ a modern corporate governance model when issuing policies for public companies, and similar developing country contexts. Our findings call for special attention to the current trend of non-CEO duality and independent external directors in legacy. The government may need to review policies relating to corporate governance applied to public firms because those policies might not have stemmed from the practice of Vietnamese firms.

In addition, the government should make substantial improvements in external corporate governance mechanisms, as suggested by Walsh and Seward (1990), because internal governance is only a part of a larger bundle of governance practices (Yoshikawa, Zhu, and Wang, 2015); this is the essence of strategic agility. Instead of forcing firms to 
adopt common rules, the government should strive to strengthen external corporate governance, such as developing strong capital markets, building effective markets for corporate control and active take-over markets, and issuing strong regulations to protect small investors, so that at least the external environment resembles more closely Western ones that are more open to competitive dynamics.

Lastly, this study suggests there are disadvantages when having two roles held by one person, suggesting that CEO duality has a negative impact on corporate entrepreneurship. CEO duality seems to be contingent on organizational factors (Boyd, 1995) or on environmental factors (Peng at el., 2007). As such, based on the specific context of each firm, the firms should choose the appropriate mechanisms that suit them, rather than just follow 'the best practices' elsewhere. CEO duality is likely to diminish the prospect of strategic agility. Vietnamese managers might also usefully recognize from the results that female managers better facilitate strategic renewal, and other control variables that might have positive impact on innovation are firms' trade on the stock market, CEO age, education and favorable locations (i.e. big cities). These factors have yet to feature in the strategic agility literature, despite micro-foundational attributes like sense making and ability to seize opportunities (Doz and Kosenon, 2008).

\section{Limitations and future research}

Remaining limitations in the methodology should be kept in mind when interpreting the study's findings and contributions. First, the cross-sectional approach does not allow for causal inferences to be made from the endogenously chosen governance, ownership and outcome variables. Future research could employ longitudinal data, which may offer new insights into the complex relationships among corporate governance, corporate entrepreneurship and strategic agility. Second, as this study focuses only on privatized firms, 
the results may not be generalized to other types of firm which do not exhibit similar characteristics. In general, board dynamics in public firms may be different from those in privatized firms. Third, as this study is based on a single country, one should be cautious about generalizing the findings to other contexts. Future research is needed to determine whether the constructs and measures used here are appropriate for other transition economies. Indeed, as entrepreneurial activities are complicated and vary significantly, the same measures should not be used in all types of research (Zahra and Wright, 2011). For example, as investments in research and development are rare in Vietnam, the inclusion of this item in the innovation construct makes it difficult to validate the measures. Moreover, as suggested by Tian and Lau (2001), it is essential to develop better concepts and measures of corporate governance in relation to specific countries. Lastly, this study has used its attributes to liken the loose conditions of strategic agility which are relatively nascent in literature, the contributions of which should be interpreted with a degree of caution even if interesting and insightful. 


\section{REFERENCES}

Adler, P., Goldoftas, B. and Levine, D. (1999), 'Flexibility vs efficiency? A case study model of changeovers in the Toyotal Production System', Organization Science, Vol.10, No. 1, pp. 43-68.

Adrian, C., Wright, S. and Kilgore, A. (2017), 'Adaptive conjoint analysis: Anew approach to defining corporate governance', Corporate Governance:An International Review, Vol. 25, No. 6, pp. 428-439.

Arbussa, A., Bikfalvi, A. and Marques, P. (2017), 'Strategic agility-driven business model renewal: the case of an SME', Management Decision, Vol. 55, No. 2, pp. 271-293.

Aubert, J.-E. (2005), 'Promoting innovation in developing countries: A conceptual framework', World Bank policy research working paper (3554).

Bergman, E. M. and J. Feser, E. (2001), 'Innovation system effects on technological adoption in a regional value chain', European Planning Studies, Vol 9, No. 5, pp. 629-648.

Bolton, P. (1995), 'Privatization and the separation of ownership and control: Lessons from Chinese enterprise reform' Economics of Transition, Vol. 3, No. 1, pp. 1-11.

Boyd, B. K. (1995), 'CEO duality and firm performance: A contingency model' Strategic Management Journal, Vol. 16, No. 4, pp. 301-312.

Brouthers, K. D., Nakos, G. and Dimitratos, P. (2015), 'SME entrepreneurial orientation, international performance, and the moderating role of strategic alliances' Entrepreneurship Theory and Practice, Vol. 39, No. 5, pp. 1161-1187.

Bui, H. T. M. and Baruch, Y. (2012), 'Learning organizations in higher education: An empirical evaluation within an international context', Management Learning, Vol 43, No. 5, pp. 515-544.

Cohen, J., Cohen, P., Stephen, G., West, S. G. and Aiken, L. S. (2003), Applied Multiple Regression/Correlation Analysis for the Behavioral Sciences. Mahwah, NJ: Lawrence Erlbaum Associates.

Connelly, B. L., Hoskisson, R. E., Tihanyi, L. and Certo, S. T. (2010), 'Ownership as a form of corporate governance. Journal of Management Studies', Vol. 47, No. 8, pp. 15611589.

Conyon, M.J. and Peck, S.I. (1998). Board control, remuneration committees, and top managemnet compensation, Academy of Management Journal, 41(2), 146-157.

Covin, J. G., and Miles, M. P. (1999). Corporate entrepreneurship and the pursuit of competitive advantage. Entrepreneurship: Theory and Practice, 23(3), 47-47.

Cycyota, C. S. and Harrison, D. A. (2002), 'Enhancing survey response rates at the executive level: Are employee- or consumer-level techniques effective?', Journal of Management, Vol. 28, No. 2, pp. 151-176

Davis, J. H., Schoorman, F. D. and Donaldson. L. (1997a), 'Davis, Schoorman, and Donaldson reply: the distinctiveness of agency theory and stewardship theory', Academy of Management Review, Vol. 22, pp. 611-613.

Davis, J. H., Schoorman, F. D. and Donaldson. L. (1997b), 'Toward a stewardship theory of management', Academy of Management Review, Vol. 22, No. 1, pp. 20-47.

Denning, S. (2018), 'Lessons in strategic agility from two Drucker Forum throught leaders', Strategy and Leadership, Vol. 46, No. 2, pp. 11-18.

DiMaggio, P. J. and Powell, W. W. (1983), 'The iron cage revisited: Institutional isomorphism and collective rationality in organizational fields', Joel A.C. Baum, 
Frank Dobbin (ed.), Economics Meets Sociology in Strategic Management (Advances in Strategic Management), Vol. 17, pp.143 - 166

Donaldson, L. and Davis, J. H. (1991), 'Stewardship Theory or Agency Theory: CEO Governance and Shareholder Returns', Australian Journal of Management (University of New South Wales), Vol. 16, No. 1, pp. 49-64.

Doz, T. L. and Kosonen, M. (2008), 'The dynamics of strategic agility, Nokia's rollercoaster experience', California Management Review, Vol. 50, No. 3, pp. 95-118.

Doz, T. L. and Kosonen, M. (2010), 'Embedding strategic ability: a leadership agenda for accelerating business model renewal', Long Range Planning, Vol. 43, pp. 370-382.

Eddleston, K. A., Chrisman, J. J., Steier, L. P. and Chua, J. H. (2010), 'Governance and trust in family firms: An introduction', Entrepreneurship Theory and Practice, Vol. 34, No. 6, pp. 1043-1056.

Eisenhardt, K. M. (1989), 'Agency theory: An assessment and review', Academy of Management Review, Vol. 14, No. 1, pp. 57-74.

Ellstrand, A. E., Tihanyi, L. and Johnson, J. L. (2002), 'Board structure and international political risk', Academy of Management Journal, Vol. 45, No. 4, pp. 769-777.

Fama, E. F. (1980), 'Agency problems and the theory of the firm', The Journal of Political Economy, Vol. 88, No. 2, pp. 288-307.

Fama, E. F. and Jensen, M. C. (1983), 'Separation of ownership and control', Journal of Law and Economics, Vol. 26, No. 2, pp. 301-325.

Filatotchev, I. (2008), 'Developing an organizational theory of corporate governance: comments on Henry L. Tosi, Jr.(2008) "Quo Vadis? Suggestions for future corporate governance research"', Journal of Management and Governance, Vol. 12, No. 2, pp. 171-178.

Finkelstein, S. and D'Aveni, R.A. (1994), 'CEO duality as a double-edged sword: how boards of directors balance entrenchment avoidance and unity of command', Academy of Management Journal, Vol. 37, No. 5, pp. 1079-1108.

Gainsborough, M. (2009), 'Privatisation as state advance: Private indirect government in Vietnam', New Political Economy, Vol. 14, No. 2, pp. 257-274.

Garrett Jr, R. P. and Holland, D. V. (2015), 'Environmental effects on the cognitions of corporate and independent entrepreneurs', Small Business Economics, Vol. 45, No. 2, pp. 369-381.

Gillespie, J. (2002), 'Transplanted company law: An ideological and cultural analysis of market-entry in Vietnam', The International and Comparative Law Quarterly, Vol. 51, No. 3, pp. 641-672.

Henrich, J., Heine, S. J. and Norenzayan, A. (2010), 'The weirdest people in the world?', Behavioral and Brain Sciences, Vol. 33, pp. 61-83.

Hurlbert, S. H., Levine, R. A. and Utts, J. (2019), ' Coup de grâce for a tough old bull: "Statistically significant" expires', The American Statistician, Vol. 73, No.1, pp. 352-357.

Ivory, S. B. and Brooks, S. B. (2018), 'Managing corporate sustainability with a paradoxical lens: lessons from strategic agility', Journal of Business Ethics, Vol. 148, pp. 347361.

Jackling, B. and Johl, S. (2009), 'Board structure and firm performance: Evidence from India's top companies. Corporate Governance: An International Review, 17(4), 492509. 
Jensen, M. C., and Meckling, W. H. (1976). Theory of the firm: Managerial behavior, agency costs and ownership structure', Journal of Financial Economics, Vol. 3. No. 4, pp. 305-360.

Kiel, G. C. and Nicholson, G. J. (2003), Bo'ard composition and corporate performance: how the Australian experience informs contrasting theories of corporate governance', Corporate Governance: An International Review, Vol. 11, No. 3, pp. 189-205.

Koriat, A., Goldsmith, M. and Pansky, A. (2000), 'Toward a psychology of memory accuracy, Annual review of psychology, Vol. 51, No. 1, pp. 481-537.

Le Breton- Miller, I. and Miller, D. (2009), 'Agency vs. stewardship in public family firms: A social embeddedness reconciliation', Entrepreneurship Theory and Practice, Vol. 33, No. 6, pp. 1169-1191.

Lewis, M. W., Andriopoulos, C. and Smith, W. K. (2014), 'Paradoxical leadership to enable strategic agility', California Management Review, Vol. 56, No. 3, pp. 58-76.

Lipton, J. P. (1977), On the psychology of eyewitness testimony', Journal of Applied Psychology, Vol. 62, No. 1, pp. 90-95.

Liu, Y., Miletkov, M. K., Wei, Z. and Yang, T. (2015), 'Board independence and firm performance in China', Journal of Corporate Finance, Vol. 30, pp. 223-244.

McMillan, J. and Woodruff, C. (2002), 'The central role of entrepreneurs in transition economies', Journal of Economic Perspectives, Vol. 16, No. 3, pp. 153-170.

Means, G. C. (1991), The Modern Corporation and Private Property, New York: Routledge.

Miller, C. C., Cardinal, L. B. and Glick, W. H. (1997), 'Retrospective reports in organizational research: A reexamination of recent evidence', Academy of Management Journal, Vol. 40, No. 1, pp. 189-204.

Misangyi, V. F. and Acharya, A. G. (2014), 'Substitutes or complements? A configurational examination of corporate governance mechanisms', Academy of Management Journal, Vol. 57, No. 6, pp. 1681-1705.

Neter, J., Wasserman, W. and Kutner, M. H. (1989), Applied Regression Models. Homewood, IL: Irwi

Nguyen, Q. A., Sullivan Mort, G. and D'Souza, C. (2015), 'Vietnam in transition: SMEs and the necessitating environment for entrepreneurship development', Entrepreneurship and Regional Development, Vol. 27, No. 3-4, pp. 154-180.

Nguyen, T. T., and van Dijk, M. (2012), 'Corruption, growth, and governance: Private vs. state-owned firms in Vietnam', Journal of Banking and Finance, Vol. 36, No. 11, pp. 2935-2948.

Nguyen, T. V. and Rose, J. (2009), 'Building trust-Evidence from Vietnamese entrepreneurs', Journal of Business Venturing, Vol. 24, No. 2, pp. 165-182.

Nguyen, V. T. (2005), 'Learning to trust: A study of interfirm trust dynamics in Vietnam', Journal of World Business, Vol. 40, No. 2, pp. 203-221.

Patton, A. and Baker, J. C. (1987), 'Why won't directors rock the boat', Harvard Business Review, Vol. 65, No. 6, pp. 10-18.

Peng, M. W., Zhang, S. and Li, X. (2007), 'CEO duality and firm performance during china's institutional transitions', Management and Organization Review, Vol. 3, No. 2, pp. 205-225. 
Podsakoff, P.M., MacKenzie, S.B. and Podsakoff, N.P. (2012), 'Sources of method bias in social science research and recommendations on how to control it', Annual Review of Psychology, Vol. 63, pp. 539-560.

Rogers, M. (2004), 'Networks, firm size and innovation', Small Business Economics, Vol. 22, pp. 141-153.

Santarelli, E. and Tran, H. T. (2012), 'Growth of incumbent firms and entrepreneurship in Vietnam', Growth and Change, Vol. 43, No. 4, pp. 638-666.

Steer, L. and Sen, K. (2010), 'Formal and informal institutions in a transition economy: The case of Vietnam', World Development, Vol. 38, No. 11, pp. 1603-1615.

Swierczek, F. W. and Thai, T. H. (2003), 'Motivation, entrepreneurship and the performance of SMEs in Vietnam', Journal of Enterprising Culture, Vol. 11, No. 1, pp. 47-68.

Tian, J. J. and Lau, C. M. (2001), 'Board composition, leadership structure and performance in Chinese shareholding companies', Asia Pacific Journal of Management, Vol. 18, No. 2, pp. 245-263.

Tran, N. T. (1999), The Fundamentals of Vietnamese Culture. Hanoi: Education Publisher.

Van Meter, K. M. (1990), 'Methodological and design issues: techniques for assessing the representatives of snowball samples', NIDA Research Monograph, Vol. 98, pp. 3143.

Van Slyke, D. M. (2007), 'Agents or stewards: Using theory to understand the governmentnonprofit social service contracting relationship', Journal of Public Administration Research and Theory, Vol. 17, No. 2, pp. 157-187.

Vu-Thanh. T. A. (2005), 'Vietnam-The long march to equitization', William Davidson Institute Policy Brief 33, Ann Arbor, MI: The William Davison Institute.

Walsh, J. P. and Seward, J. K. (1990), 'On the efficiency of internal and external corporate control mechanisms', Academy of Management Review, Vol. 15, No. 3, pp. 421-458.

Wang, Y.-K. M., Chung, C. C. and Lim, D. S. (2015), 'The drivers of international corporate entrepreneurship: CEO incentive and CEO monitoring mechanisms', Journal of World Business, Vol. 50, No. 4, pp. 742-753.

Wasserman, N. (2006), 'Stewards, agents, and the founder discount: Executive compensation in new ventures', Academy of Management Journal, Vol. 49, No. 5, pp. 960-976.

Weber, Y. and Tarba, S. Y. (2014). 'Strategic agility: a state of the art - Introduction to the special section on strategic agility', California Management Review, Vol. 56, No. 3, pp. 5-12.

Westphal, J. D. (1999), 'Collaboration in the boardroom: Behavioral and performance consequences of CEO-board social ties', Academy of Management Journal, Vol. 42, No. 1, pp. 7-24.

Wiklund, J. (1999), 'The sustainability of the entrepreneurial orientation-performance relationship', Entrepreneurship Theory and Practice, Vol. 24, No. 1, pp. 37-48.

Yoshikawa, T., Zhu, H. and Wang, P. (2014), 'National governance system, corporate ownership, and roles of outside directors: A corporate governance bundle perspective', Corporate Governance: An International Review, Vol. 22, No. 3, pp. 252-265.

Zahra. S. A. (1993), 'A conceptual model of Entrepreneurship as firm behavior: a critique and extension', Entrepreneurship Theory and Practice, Vol. summer, pp. 5-21. 
Zahra. S. A. (1996), 'Goverance, ownership, and corporate entrepreneurship: The moderating impact of industry technological opportunities', Academy of Management Journal, Vol. 39, No. 6, pp. 1713-1735.

Zahra, S. A., Neubaum, D. O., and Huse, M. (2000), 'Entrepreneurship in medium-size companies: exploring the effects of ownership and governance systems. Journal of Management, Vol. 26, No. 5, pp. 947-97.

Zahra, S. A. and Wright, M. (2011), 'Entrepreneurship's next act', The Academy of Management Perspectives, Vol. 25, No. 4, pp. 67-83. 
Table 1: Correlations between Variables

\begin{tabular}{|c|c|c|c|c|c|c|c|c|c|c|c|c|}
\hline Variable & Mean & SD & 1 & 2 & 3 & 4 & 5 & 6 & 7 & 8 & 9 & 10 \\
\hline 1. Innovation & 2.32 & 1.28 & $(.85)$ & & & & & & & & & \\
\hline 2. Strategic Renewal & 3.55 & 1.16 & .56 & $(.74)$ & & & & & & & & \\
\hline 3. CEO duality & .59 & .51 & -.12 & -.23 & & & & & & & & \\
\hline 4. CEO gender & 1.07 & .26 & .11 & .23 & -.11 & & & & & & & \\
\hline 5. CEO age & 51.96 & 7.53 & -.01 & -.24 & .25 & -.02 & & & & & & \\
\hline 6. CEO education & 3.13 & .53 & .30 & .26 & .04 & .06 & -.31 & & & & & \\
\hline 7. CEO tenure & 19.12 & 10.00 & .05 & .07 & .05 & .03 & .49 & -.14 & & & & \\
\hline 8. Firm location & 2.43 & 1.11 & -.36 & -.18 & .15 & -.03 & .15 & -.21 & .02 & & & \\
\hline $\begin{array}{l}\text { 9. Trade on stock } \\
\text { market }\end{array}$ & .30 & .46 & .33 & .30 & -.23 & .19 & .06 & .02 & .12 & -.12 & & \\
\hline 10. Board size & 4.94 & 1.47 & .33 & .37 & -.13 & .16 & -.05 & .07 & .20 & -.15 & .41 & .03 \\
\hline
\end{tabular}

Notes: Cronbach Alpha values in brackets; SD: standard deviation 
Table 2: Results of Regressions

\begin{tabular}{|c|c|c|c|c|c|c|}
\hline \multirow[b]{2}{*}{ Variables } & \multicolumn{3}{|c|}{$\begin{array}{c}\text { Innovation } \\
\text { (Model 1) }\end{array}$} & \multicolumn{3}{|c|}{$\begin{array}{c}\text { Strategic Renewal Performance } \\
\text { (Model 2) }\end{array}$} \\
\hline & $\underline{\beta}$ & $\varepsilon$ & $p$ & $\bar{\beta}$ & $\varepsilon$ & $p$ \\
\hline Intercept & & 2.56 & .06 & & 2.4 & .51 \\
\hline Control & & & & & & \\
\hline CEO gender & -.01 & .42 & .90 & .15 & .39 & .10 \\
\hline CEO age & .24 & .02 & .04 & -.14 & .02 & .22 \\
\hline CEO education & .29 & .22 & .00 & .19 & .21 & .05 \\
\hline CEO experience in firm & -.05 & .01 & .61 & .14 & .01 & .19 \\
\hline Firm size & .17 & .00 & .09 & -.00 & .00 & .98 \\
\hline Firm location & -.18 & .11 & .04 & .01 & .10 & .88 \\
\hline Firm assets & .16 & .20 & .21 & .20 & .19 & .14 \\
\hline Trade on stock market & .20 & .30 & .07 & .15 & .28 & .18 \\
\hline Board size & .13 & .09 & .21 & .16 & .09 & .15 \\
\hline CEO duality & -.13 & .25 & .19 & -.12 & .23 & .21 \\
\hline$R^{2}$ & .36 & & & .33 & & \\
\hline$F$ & 1.7 & & & 1.6 & & \\
\hline$N$ & 114 & & & 114 & & \\
\hline
\end{tabular}




\section{Appendix 1: Corporate entrepreneurship (CE) scale and association with strategic}

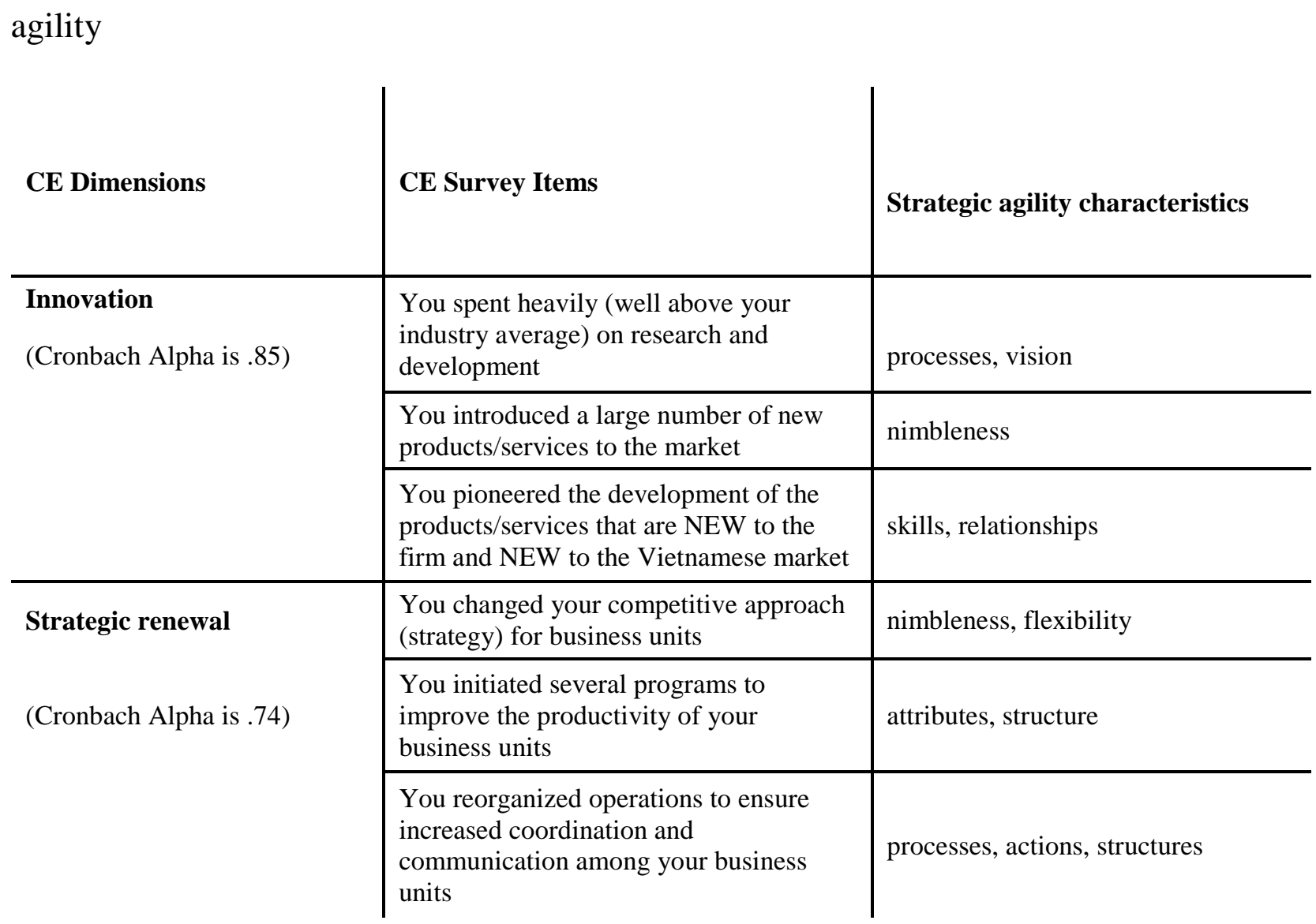

